\section{Intersections}

Canadian Journal of Music

Revue canadienne de musique
Intersections CANADIAN JOURAL OF MUSIC

\title{
Brian Cherney as Scholar and Creative Artist
}

\section{Robin Elliott}

Volume 37, numéro 1, 2017

Illuminations: Essays in Honour of Brian Cherney

URI : https://id.erudit.org/iderudit/1059886ar

DOI : https://doi.org/10.7202/1059886ar

Aller au sommaire du numéro

\section{Éditeur(s)}

Canadian University Music Society / Société de musique des universités canadiennes

ISSN

1911-0146 (imprimé)

1918-512X (numérique)

Découvrir la revue

Citer cet article

Elliott, R. (2017). Brian Cherney as Scholar and Creative Artist. Intersections, 37(1), 39-52. https://doi.org/10.7202/1059886ar

\section{Résumé de l'article}

Bien que connu surtout comme compositeur, Cherney a aussi été actif dans le milieu de l'érudition musicale. Sa thèse de doctorat en musicologie portait sur la critique musicale sous la République de Weimar; plus tard dans sa carrière, il a aussi fait des interventions importantes et opportunes dans le domaine des études musicales au Canada. Ses publications incluent des articles sur John Weinzweig et Pierre Mercure, ainsi qu'une monographie sur Harry Somers, qui fait l'objet de sa recherche en cours. Son cours sur la musique canadienne à l’Université McGill a initié de nombreux étudiants à l'étude sérieuse et la compréhension de la musique composée au Canada. Cet essai porte sur l'érudition musicale de Cherney et pose comme hypothèse que cette optique peut avoir influencée ses activités créatrices comme compositeur.
Copyright @ Canadian University Music Society / Société de musique des universités canadiennes, 2019
Ce document est protégé par la loi sur le droit d'auteur. L'utilisation des services d'Érudit (y compris la reproduction) est assujettie à sa politique d'utilisation que vous pouvez consulter en ligne.

https://apropos.erudit.org/fr/usagers/politique-dutilisation/ 


\title{
BRIAN CHERNEY AS SCHOLAR AND CREATIVE ARTIST
}

\author{
Robin Elliott
}

The scholar-composer is a characteristic manifestation of contemporary North American music culture, ensconced in university music departments, schools, and faculties the length and breadth of the continent. Taught graduate degree programs in composition were introduced in the mid-twentieth century and spread rapidly after World War II. By the 196os, dozens of universities were offering doctoral degree programs in composition as the ultimate in academic credentials for aspiring composers.

Brian Cherney, however, belongs to a much rarer breed of scholar-composer: those with a $\mathrm{PhD}$ in musicology. The most famous such example is Anton Webern, who completed his doctoral degree under the supervision of Guido Adler at the University of Vienna in 1906. Another composer with a doctorate in musicology from the University of Vienna was Gerhard Wuensch (19252007), who completed his degree there in 1950. ${ }^{1}$ Wuensch taught at the University of Toronto from 1964 to 1969 , having moved there at the invitation of fellow Austrian émigré Arnold Walter. It was Wuensch who first drew Cherney's attention to the argument between the composer Hans Pfitzner and the music critic Paul Bekker during the post-World War I era in Weimar Germany. This was soon to become the subject of Cherney's doctoral research in musicology at the University of Toronto.

Cherney was born in 1942 in Peterborough, Ontario. ${ }^{2}$ As a teenager, he travelled to Toronto weekly for advanced piano lessons at the Royal Conservatory

1 In the program note to his Trio, op. 1 for clarinet, bassoon, and piano (1948), Wuensch wryly stated, "One of the greatest benefits derived from my musicological studies was the realization of the total insignificance of my talents as a composer" (MacMillan and Beckwith 1975, 245). Cherney has made similarly amusing self-deprecatory comments about his work as a composer; e.g., the preface to Brahms and the German Spirit (2009), in which he cites various condemnatory (but fictitious) reviews of his work, and the entertaining autobiographical vignette he created in 2017 for the Marvin Duchow Music Library display titled "The Score's the Thing: Humour and the Absurd in the Music of Brian Cherney."

2 Biographical material in this paragraph is based on conversations with Cherney, and on Cornfield and Montagna (2005), which, however, make no mention of Cherney's doctoral degree in musicology, or his interest in music scholarship. In this issue of Intersections, the articles by Zosha Di Castri and Cherney, and Cherney's interview with Chris Harman, all cast further light on Cherney's life story and his early years as a pianist and composer. 
of Music. A love for improvising at the piano led to composition lessons with George Crumb at Interlochen Music Camp one summer, then to further lessons with Samuel Dolin at the Royal Conservatory of Music in Toronto. During his undergraduate studies in the Faculty of Music at the University of Toronto, however, Cherney majored in musicology. ${ }^{3}$ He graduated in 1964 and then switched to composition for his MMus, studying with John Weinzweig and graduating in 1967 . He continued on to doctoral studies, but practical considerations led to a decision to enrol not for a MusDoc in composition, but rather a $\mathrm{PhD}$ in musicology. Cherney felt that a doctorate in musicology would be more likely than a degree in composition to lead to a career in academia. (This belief turned out to be misplaced, as Cherney's appointment to McGill in 1972 was as a professor of analysis and composition, rather than musicology.) Arnold Walter was the éminence grise of music scholarship at the University of Toronto at the time. However, given Walter's reputation for being an austere, remote, and demanding supervisor, Cherney opted to work instead with the composer Gustav Ciamaga as his academic supervisor. ${ }^{4}$ Although Ciamaga was more active in composition and electronic music than in music scholarship, he had studied musicology as a graduate student at Brandeis University.

Cherney's thesis was completed late in 1973, with the defence taking place in April 1974 (Cherney 1973). Based on research done in Germany from 1969 to 1970, the thesis examines the reception of new music during the Weimar era, in light of the polarization of opinion between conservative and progressive music critics, as highlighted by the disagreement between Pfitzner and Bekker. The Weimar Republic was created in 1919, and that same year Pfitzner completed a pamphlet titled The New Aesthetic of Musical Impotence, in which he attacked Bekker, Germany's most widely read music critic and an influential champion of new music. Bekker replied to Pfitzner in two articles published in January 1920 in the Frankfurter Zeitung newspaper, of which he was the chief music critic and which had a wide circulation throughout Germany. The critical sallies between Pfitzner and Bekker foreshadowed a polarization of musical opinion that would characterize music journalism throughout the entire Weimar era. Adding poison to the disagreement were Pfitzner's anti-Semitic slurs against Bekker. Although Bekker's mother was Christian and he was raised as a Lutheran, the fact that his father was Jewish marked him out for discrimination by Pfitzner, and later by the Nazis, leading to his decision to leave Germany. He emigrated to Paris in January 1934 and later that same year moved to New York City, where he was active as a music critic and lecturer before his untimely death in 1937. Pfitzner remained in Germany throughout the Third Reich, and died in Salzburg in 1949.

3 Beckwith et al. $(1990,61)$ state that Cherney completed a MusBac in performance, but this is incorrect; his undergraduate degree was in History and Literature, i.e., musicology. Cherney states, "I had done the first year of the Artist Diploma in piano but then switched to the B.Mus. program in History and Literature. The directory is wrong" (email communication, 27 May 2018).

4 Helmer $(2009,116-17)$ cites examples of students who were intimidated by Walter's compendious knowledge and Old World manners; his circle was "like out of a novel by Thomas Mann" in Helmut Kallmann's words. However, Helmer also quotes Alan Gillmor's testimonial that Walter was a superb PhD supervisor. Walter died in October 1973, just as Cherney was completing his PhD thesis. 
In the research for his thesis, Cherney read hundreds of music reviews in dozens of German newspapers and periodicals from the 1920 and early 1930 . The thesis includes many extensive quotations in German from these reviews, demonstrating Cherney's high degree of fluency in the language-a sine qua non for musicology students at the University of Toronto (as elsewhere) at that time. Cherney demonstrates that the Weimar era, though often celebrated as a time of musical experimentalism and cosmopolitan culture, was characterized by deep-seated and ongoing tensions between conservative and progressive elements, in both music and society. Though the Pfitzner-Bekker controversy is the main topic of the thesis, its major contribution to music scholarship is perhaps the thoroughness with which it examines the broader culture of music and especially music criticism during the Weimar era.

The progressive critics - many, though not all of them, Jews-included Bekker and other eminent figures such as Theodor Adorno, Alban Berg, and Hans Heinz Stuckenschmidt. The conservative writers included men such as Karl Blessinger, Georg Graener, and Eugen Schmitz. These three men and other like-minded conservative critics went on to play decisive roles in the Nazi musical hierarchy. Blessinger's Judentum und Musik is a particularly egregious example of the depths to which musicologists were willing to plunge in order to bring their work in line with the Gleichschaltung edicts of the Nazi authorities (Blessinger 1944). Cherney sheds light on the deeper themes that underlay the opposing aesthetic viewpoints of the two sides-the relationship of new music to German musical traditions of the past, the role of inspiration versus intellect in the process of composition, the degree of openness to foreign music and ideas, and the role that political and nationalist themes played in the music criticism of this period. For the conservative critics, the music itself often served as a mere pretext for vitriolic commentaries that were rife with nationalist, chauvinist, and racist turns of phrase-a rhetoric that paved the way, as Cherney notes, for the oppressive and restrictive musical conditions of the Third Reich.

Cherney states that those who supported radical new musical idioms of the era were most often left wing in their political views, while those who opposed such music were right wing (Cherney 1973, especially chapter 7, "Politics and Nationalism"). This somewhat oversimplifies the situation. Schoenberg and Webern were both ardent German nationalists, a trait that Cherney associates with the conservative stream in the Weimar era, but their music was at the vanguard of the radical, progressive stream at this time. The case of Webern is indicative of the complexities involved. Though enthusiastic about Hitler and exulting in German victories at the start of the war, he also actively sheltered Jews after the Anschluss, including Schoenberg's son Georg. The evident difficulty in coming to any firm conclusions about the political views of individual musicians means we should be hesitant about attempting to establish broad relationships between musical opinions and political ideas. As Alex Ross notes, "The automatic equation of radical style with liberal politics and of conservative style with reactionary politics ... does little justice to an agonizingly ambiguous historical reality" (Ross 2007, 346). 
There was not much literature in English on Weimar musical culture before Cherney's thesis, and almost none on the Bekker-Pfitzner quarrel, but a good deal has appeared since then. ${ }^{5}$ Peter Franklin noted that previous accounts in English of the Bekker-Pfitzner quarrel (not including Cherney's thesis, which he does not cite) "tended to give the impression that it was primarily [a sideline to the] one between Pfitzner and Alban Berg" (Franklin 1989, 82n6). ${ }^{6}$ John Williamson in The Music of Hans Pfitzner includes an extensive commentary on the quarrel with Bekker and sheds light on its origins in a similar dispute between Pfitzner and Busoni three years earlier (Williamson 1992, 23-47). Marc Weiner in Undertones of Insurrection devotes a forty-page chapter to the polemical writings of Pfitzner (Weiner 1993, 33-71), while the chapter on Pfitzner in Michael Kater's book Composers of the Nazi Era: Eight Portraits concentrates on Pfitzner's cantankerous relationship with Nazi officials, but also deals in passing with the Bekker quarrel (Kater 2000, 149). None of these sources cites Cherney's thesis. More recently, however, Ian Pace in his doctoral thesis on new music in West Germany after 1945 and its roots in the Weimar era does include several references to Cherney's thesis (Pace 2018). Nanette Nielsen's recent book Paul Bekker's Musical Ethics is the first substantial study of Bekker in English (Nielsen 2018). It is based on research Nielsen did in the Bekker papers, which were donated to the Irving S. Gilmore Library at Yale University in 1983, but it too does not cite Cherney.

Although later scholars have largely ignored Cherney's work on the quarrel between Bekker and Pfitzner, his research on music criticism has had a modest impact on later scholarship. Marc-André Roberge (who completed his $\mathrm{PhD}$ in musicology at the University of Toronto in 1988) brought attention to Cherney's observation that beneath the glittering, cosmopolitan, experimental surface of Weimar culture there lay a bedrock of traditionalism, a phenomenon that Cherney labels the "conservative syndrome" (Roberge 1994, 72, citing from Cherney 1973, 3). Brendan Fay's PhD thesis in history at Indiana University on music in Weimar takes as its starting point Cherney's "conservative syndrome" (Fay 2013,6$)^{8}$ and goes on to consider specific case studies of how conservative critics responded to inflation, technology (radio and recordings), internationalism, and race (i.e., the Jewish influence on and presence in German music). Nicholas Attfield has written the most recent and nuanced treatment of the conservative strain in Weimar musical culture, but he does not reference Cherney's thesis (Attfield 2017).

It is unfortunate that Cherney's thesis, which is based on an unprecedentedly thorough and probing analysis of Weimar-era music criticism, did not have

5 The US music critic John Rockwell completed his study of Weimar musical culture just before Cherney (Rockwell 1972). The thesis forms the basis for his much later article on opera reform in the Weimar republic (Rockwell 2006).

6 Cherney $(1973,126-7)$ deals with Berg's rebuttal of Pfitzner's The New Aesthetic of Musical Impotence.

7 Bekker's quarrel with Pfitzner receives the briefest of mentions (Nielsen 2018, 30 and 158). For further information on Bekker, see Hailey $(1993,1994)$.

8 Fay uses an abbreviated version of the same quotation from Cherney's thesis as is found in Roberge $(1994,7)$. 
a bigger impact on subsequent studies of the Bekker-Pfitzner quarrel and the polarized musical culture of Weimar Germany. Part of the reason for this may be that Cherney's reputation as a composer soon eclipsed that of his standing as a musicologist. Furthermore, Cherney did not promote his musicological research after completing his thesis in 1974. There are no articles or other publications by him derived from the thesis that would have drawn wider attention to his work on the Weimar era. But this is understandable, because by the time of his thesis defence in April 1974, his own music research interests had already turned decisively to the field that would occupy him from that point to the present: Canadian music.

Keith MacMillan, the executive secretary of the Canadian Music Centre, approached Cherney in December 1971, at the suggestion of John Beckwith, to invite him to write a book on either John Weinzweig or Harry Somers. Cherney was busy at work on his $\mathrm{PhD}$ thesis but was willing to turn his attention to a new research challenge. By the end of 1971 he had chosen to write about Somers-with unfortunate consequences for Weinzweig, who would wait another twenty-two years for his biography to appear. ${ }^{9}$ Cherney submitted the first two of the eight chapters of the Somers book in May 1973 and delivered the rest later that summer. Further corrections and additions, along with the bibliography, discography, and list of works, were completed in September 1974, just five months after Cherney's thesis defence. In January 1975 Cherney's wife Terri was contracted to do the index for the book, after which it went into production. The book was published in September 1975, which coincided with Somers's fiftieth birthday that month (on 11 September), and with the Canadian Opera Company's revival of Somers's magnum opus, the opera Louis Riel (which opened on 27 September).

During the period he was working on this biography, Cherney also wrote an extensive article on Somers for the reference book Contemporary Canadian Composers (Cherney 1975b), which was published in 1975, the same year as Cherney's book. ${ }^{10}$ The fact that during this period Cherney managed to complete all of this work on Somers, begin his academic career at the University of Victoria in 1971 and then at McGill in 1972, write several major compositions, and finish his $\mathrm{PhD}$ thesis, as well as get married and start a family, is indicative of his extraordinarily disciplined work ethic and an impressive rate of both scholarly and creative productivity.

Before Cherney's book, there was very little scholarly literature on Somers. Cherney was thus faced with creating a narrative about Somers's life story virtually from scratch and providing a comprehensive analytical framework for

9 Richard Henninger and Gustav Ciamaga successively undertook to write the biography of Weinzweig for the University of Toronto Press's Canadian Composers series of monographs, only to relinquish the project later. Elaine Keillor then picked up the project; her biography was published in Scarecrow's Composers of North America series (Keillor 1994). Correspondence pertaining to both the Somers and Weinzweig biography projects is in the John Beckwith papers in the University of Toronto Faculty of Music Library, file 10.C.3.1971-1991/4.

10 Cherney later wrote two other encyclopedia articles on Somers (Cherney 1980, 1981). 
understanding his music as well. ${ }^{11} \mathrm{He}$ rose to both tasks brilliantly, the former by doing extensive interviews with Somers as well as with a handful of his closest mentors and associates, and the latter by closely examining a wide selection of Somers's scores, including early works in manuscript that were not in circulation but that the composer lent to him. In the Acknowledgments, Cherney writes, "This study is not intended to be a complete biography of Harry Somers; nor, in view of his prolific output, is it an exhaustive study of his music" (Cherney 1975a, xii). Nevertheless, the book is the foundation for all further work on the composer, of which there has been not nearly enough. Cherney's own research on Somers is ongoing, and while not many others have followed up on his suggestion that his book should serve as "a framework and point of departure for further exploration of [Somers's] music" (Cherney 1975a, xii), fortunately Cherney himself is doing so.

At the time of its publication, Cherney's book was arguably the finest study ever written of a Canadian composer. It launched the University of Toronto Press's Canadian Composers monograph series and was dedicated to Somers on the occasion of his fiftieth birthday. A review of the book by John Kraglund in the Globe and Mail, however, faulted Cherney for his "pedantic style," for excessive analytical material in the book (which he felt would alienate "the ordinary concert-goer"), and for a lack of emphasis on biographical material (Kraglund 1975). In a letter to the editor of the newspaper, John Beckwith came to the defence of Cherney's book by providing a detailed point-by-point rebuttal of Kraglund's "unusually petulant review" (Beckwith 1975). ${ }^{12}$ The biography received a more detailed and insightful review by Alan Gillmor in the UK journal Contact: Today's Music. While noting that Cherney does not offer much insight into Somers the man, and that his writing style is "a bit stiff and perfunctory," Gillmor nevertheless salutes the book as providing "clear evidence that scholarly musical criticism in Canada has arrived at a new level of maturity and professionalism" and calls it "the first truly important document of ... critical musical commentary in Canada" (Gillmor 1977).13

Commenting on Somers's composition teacher, John Weinzweig, Cherney writes that he "was regarded by many established musicians as a fifth columnist, bent on destroying the traditional nineteenth-century musical language ... remember that in the early forties Toronto's musical life was deeply rooted in the nineteenth century" (Cherney 1975a, 9). A Jewish radical composer upsetting the conservative critics with a progressive musical idiom-the parallel with the situation in Weimar Germany in the 1920s is striking. One important difference is that music criticism in Canada was lamentably underdeveloped as compared to Germany in the earlier generation. There were scarcely any progressive critics coming to the defence of new music in Canada; indeed, there

11 The most important earlier study is Olnick (1959). Somers was only thirty-three years old when Olnick's article was published.

12 Beckwith was the chairman of the Canadian Music Centre's publication committee, under whose aegis Cherney's biography was published.

13 Gillmor was a graduate student at the University of Toronto at the same time as Cherney, completing his PhD thesis, "Erik Satie and the Concept of the Avant-Garde," in 1972. 
were few serious music critics at all. As a result, it was left to the composers themselves to argue the case for new music, a cause taken up with eloquence and passion by Cherney as well as by Istvan Anhalt, John Beckwith, Gustav Ciamaga, Clifford Ford, Udo Kasemets, Bruce Mather, Barbara Pentland, and John Weinzweig, among others.

One recent outcome of this activism by composers is Weinzweig: Essays on His Life and Music (Beckwith and Cherney 2011a). Unlike the previous book on Weinzweig, which was twenty-two years in the making, this one was produced in just under five years, from the initial idea in the spring of 2006, to the book launch on 13 January 2011. (Weinzweig was aware of the project but died on 24 August 2006, shortly after its inception.) In addition to co-editing the book, Cherney co-authored the biographical chapter (Beckwith and Cherney 2011a) and contributed an essay on Weinzweig's work as an activist on behalf of Canadian music (Cherney 2011). In the latter essay he traces the possible origins of Weinzweig's activism to his father's participation, before migrating to Canada from his native Poland, in the Bund, a socialist East European Jewish workers' movement. Cherney speculates that Weinzweig's energy and his personal ambition to see contemporary composition established as a respectable activity in Canada were the two other factors that contributed to his persistent and ongoing activist efforts to promote the cause of contemporary Canadian music.

As we have seen, Cherney shares with his former teacher Weinzweig that boundless energy and activist mindset. Cherney's annual Canadian music course at McGill University, with its carefully curated public concert, is a kind of educational activism on behalf of Canadian music, and it has introduced many students to the serious study and understanding of composed music in Canada. The public concerts (see Maskell 2017 and Cherney 2018 for representative recent examples) have presented a wide range of Canadian music over the years, ranging from very recent works to seldom-performed repertoire from earlier in the century. Also worth noting is a fine article (in French) on the Quebec composer Pierre Mercure (Cherney 2014), in which Cherney offers a detailed analysis of two orchestral works, Triptyque (1959) and Lignes et points (1964). The article closes by comparing Mercure with his contemporary Harry Somers, noting that they were the two leading avant-garde Canadian composers of their day.

Cherney's scholarly and creative work have had a close connection with one another. Throughout his graduate studies at the University of Toronto, Cherney's interests ranged across both composition and musicology. During the 1969-70 academic year, while living in Munich, Cherney not only pursued musicological research, he also attended the Donaueschingen and Darmstadt new music festivals. The Donaueschingen visit combined his musicological and compositional interests, for Cherney devotes a section of his thesis (1973, $196)$ to a study of the early years of that festival.

Immediately after returning to Canada in 1970 from his research stay in Germany, Cherney worked not only on his thesis, but also on his Second String Quartet, which he completed in November of that year. It is an intensely 
personal and expressive work, dedicated to the memory of the composer's recently deceased mother, with theatrical gestures, extended string playing techniques, and subtle but evocative quotations from the music of Beethoven and Grieg, references that are musically engaging for the listener, but also full of personal significance for the composer. ${ }^{14}$ Such quotations and allusions abound in Cherney's music. They are inserted with a musicologist's scrupulous attention to detail and a composer's inspiration and creativity. ${ }^{15}$ The first performance of Cherney's String Quartet No. 2 by the Czech String Quartet in Hamilton early in 1971 occasioned a particularly hostile review in the local newspaper (Betts 1971). Perhaps Cherney was struck by the fact that the splenetic tone of the review would not have been out of place in 1920 B Berlin.

Cherney's Brahms and the German Spirit (2009) offers a rich case study for the mutual influence of his interests in composition and musicology (and, in this case, in the graphic arts and collage). ${ }^{16}$ The score incorporates a visual collage of pictures of Brahms, Gustav and Alma Mahler, and their contemporaries, as well as East European Jewish street scenes and klezmer musicians. Many of the figures have speech bubbles, which contain texts-in English, German, or Yiddish-or short musical quotations. None of this material is meant to be performed-it is a type of silent Augenmusik. ${ }^{17}$ The work is thus intended to be read as a text as much as, or perhaps even more than, it is to be heard as music; the impetus behind it was as much musicological as it was creative. Elsewhere in this issue of Intersections, Beckwith, Harman, and Cherney himself have interesting observations about this work. Beckwith compares the richly illustrated score to a graphic novel (see p. 25). Harman posits that it could be considered "a kind of theatrical research-creation project" (p. 37). The paratextual commentary in part lampoons Brahms's relations to women. As Swafford notes succinctly, "For intimate female companionship Brahms ... relied on

14 For a discussion of Cherney's String Quartet No. 2, see Elliott (1990, 186-91) and Cherney (1974, 10-11 and 13).

15 Desjardins makes a similar point: "Le musicologue qu'il est aussi rappelle toujours au compositeur le poids de la tradition et sa musique témoigne d'un grand respect envers les maîtres du passé. C'est pourquoi ses oeuvres sont truffées de citations, soigneusement choisies pour servir les objectifs du moment" (Desjardins 1999, 18).

16 The work was commissioned by the cellist Elise Pittenger for performance in her doctoral lecture-recital and was premiered by her, with the clarinetist Louise Campbell, in Tanna Schulich Hall at McGill University on 11 January 2010. Pittenger also writes about the piece briefly in her doctoral thesis (Pittenger 2010, 47-49).

17 The silent music vignettes include the opening of the Brahms Clarinet Trio, op. 114 (p. 1); the German folksongs "Ich bin so lang nicht bei dir g'west" (which features in the final variation of Bach's Goldberg Variations) and "Mein junges Leben hat ein End" (p. 3); bars 33 to 37 of the piano part of the first movement of the Brahms Clarinet Trio (p. 4; if a pianist is participating, this vignette is played); the Viennese folksong "Ach, du lieber Augustin," which featured prominently in Mahler's psychoanalytic session with Freud (pp. 5, 11); bars 45 to 49 of the third and fourth clarinet parts of the third movement of Mahler's Symphony No. 1 (p. 6); bars 83 to 90 of the piano part of the first movement of the Brahms Clarinet Trio (p. 8; again, this is heard if a pianist is participating); excerpts from the Brahms German Requiem (pp. 13, 14); and the opening of the third movement of Mahler's Symphony No. 1 (p. 15). An additional quotation worth noting is not silent, but rather is played by the clarinet on p. 7; this is the music that portrays the whinging of the poor Jew Schmuÿle in the movement "'Samuel' Goldenberg and 'Schmuÿle" from Mussorgsky's Pictures at an Exhibition; Taruskin calls the movement "a distasteful portrayal of two loathsome Jewish mugs" (Taruskin 1993, 382). 
brothels" (Swafford 1997, 546), and Cherney has some fun with this aspect of Brahms's life story. More seriously, Beckwith, Cherney, and Harman all note the dark underlying message in the work about the close relationship between German high culture and the Holocaust. What began as a work of creativity-an instrumental music theatre piece for clarinet and cello, with optional piano-became, with the addition of paratextual images and texts, a probing and provocative intervention into Brahms reception and Brahms scholarship. There is a large scholarly literature on the relationship between Wagner and the Nazis, but Cherney's work is one of the few to position Brahms squarely within the rise of German nationalism and anti-Semitism in Vienna that led inexorably to the Holocaust. When the Viennese Stock Exchange crashed on 9 May 1873, right-wing observers blamed it on "Jewish capitalism." This financial crisis led to the rise during Brahms's lifetime of an openly anti-Semitic political culture in Vienna that spawned the likes of Georg von Schönerer and Karl Lueger-and eventually Adolf Hitler. ${ }^{18}$

Cherney borrowed the title for his work from a book by the Brahms scholar Daniel Beller-McKenna (Beller-McKenna 2004). The book examines the relationship of Brahms and his music to late nineteenth-century German nationalism. It is a response to post-war Brahms scholarship, which tried to neutralize the figure of "Brahms the German" in order to remove any lingering taint of Nazi association. In response to my question as to whether or not the Beller-McKenna book influenced his composition, Cherney replied that it did not: "As far as I can remember, I discovered the book when I was well into the project-in its 'pictorial score' stage-and probably did myself no favour by borrowing the title of the book. But no aspect of the piece was influenced by the book itself, as far as I can remember. So, no, the piece was not a response to the book" (Cherney email communication, 2 February 2018).

Nevertheless, there are striking parallels between the book and the composition. The third chapter of Beller-McKenna's book is about Brahms's German Requiem, op. 45, and Cherney inserts three quotations from that work into the Augenmusik of his score. ${ }^{19}$ The final chapter of the book is about the posthumous reception of Brahms's music, including a consideration of the role that Brahms's music played in the Weimar Republic and the Third Reich.

Cherney's Brahms and the German Spirit opens with an arresting epigraph: the first verse of Paul Celan's poem "Schwarze Flocken" (Black flakes). The poem was written late in 1942 (shortly after Cherney's birth), in response to the abduction of Celan's parents in June 1942. He never saw them again and later learned of their deaths at the hands of the Nazis. ${ }^{20}$ The black flakes of

18 Hitler turned eight in the month that Brahms died, and moved to Vienna ten years after Brahms died in that city.

19 A young boy sings the opening soprano melody of the last movement, "Selig sind die Toten," on p. 13; the autograph manuscript of the first page of the second movement, "Denn alles Fleisch es ist wie Gras," is on p. 14; and the complete text of the last movement is quoted on p. 16.

20 Cherney quotes the poem both in the original German, and in an English translation by John Felstiner (2001, 15). In 2006, three years before Cherney wrote Brahms and the German Spirit, the German artist Anselm Kiefer (b. 1945) created a darkly compelling artwork inspired by and taking its name from this same poem by Celan. 
Celan's poem are a potent symbol. They are the ashes of burned substancespaper, trees, corpses; the sole remaining traces of incinerated books, landscapes, people. A stark image of "that which happened," as Celan called the Holocaust (Felstiner 2001, xxi). ${ }^{21}$ Black flakes recur throughout the pages of Cherney's score, falling onto images of East European Jews, including a klezmer clarinetist. At the end (figure 1) there is a framed image that consists of nothing but black. As Beckwith aptly notes earlier in this issue, this final black image symbolizes "the eradication of Jewish culture in Eastern Europe beginning in the Germany and Austria of Brahms's time" (p. 26).

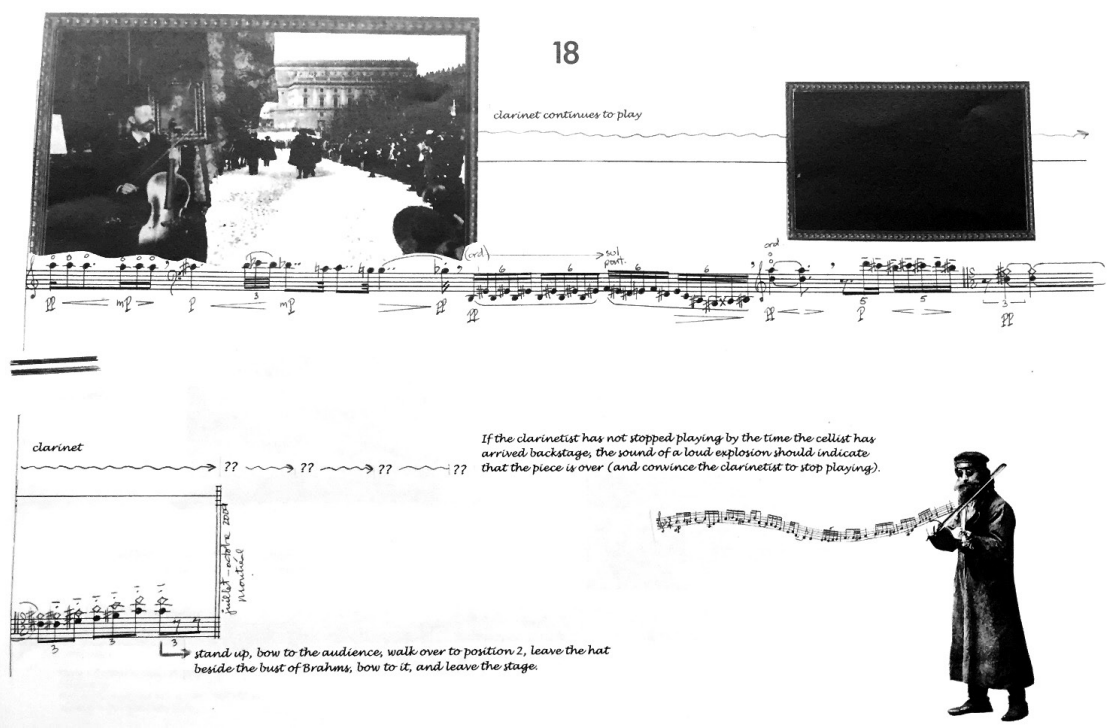

Figure 1. Brian Cherney, Brahms and the German Spirit (2009), p. 18 of the score

A recurring image in the score is a picture of a trager, an itinerant Jewish labourer who frequented markets and train stations, offering to carry heavy boxes or luggage. He first appears beneath the Celan quotation at the start of the score and returns on pages 9 and 15 . He has a speech bubble on page 9 (in Yiddish) that reads:

Of course, there's no evidence that Brahms had any awareness of the class struggle. No books on Marxist theory in his library, no association with the working class (despite his humble origins). He clearly belonged to the haute bourgeoisie and was probably a Liberal-a member of the educated upper-middle class. He would never have written music for the working classes, like Cornelius Cardew or Frederic Rzewski ... after all, he was friends with the Wittgensteins and was always at the Griensteidl. (Source of the translation: Cherney email communication, 27 May 2018)

21 A related image is "Schwarze Milch" (black milk), a recurring phrase in Celan's most famous poem, "Todesfuge" (Death fugue). 
On page 15 the trager is pictured next to Brahms (who is on his deathbed), with another speech bubble in Yiddish that roughly translates as "I've never seen so many widows show up at one man's funeral. Perhaps I should leave him here." Cherney suggests that the trager is perhaps there "to carry Brahms off to the next world" (email communication, 28 May 2018).

Among the great composers of the later nineteenth century, it is difficult to find one who was not anti-Semitic to some degree. Brahms, by contrast, enjoyed many close friendships with Jews and, as Swafford notes, "may have idolized Bismarck and the authoritarian Prussians, but he remained a liberal and a democrat at heart" (Swafford 1997, 425). After the election of the anti-Semitic politician Karl Lueger as the mayor of Vienna, Brahms is reported to have been horrified and to have stated, "Anti-Semitism is insanity."22 Nevertheless, Margaret Notley notes that Brahms "was guilty of occasional remarks that we would now consider to be anti-Semitic" (Notley 1993, 110). The most telling is his statement, "If the endless reinforcement of Galician Jews in Vienna were hindered, I would be in favor of it" (110). ${ }^{23}$ Cherney inserts this quotation, in the original German, on page 11, as a speech bubble from the mouth of Brahms, who is pictured observing a Viennese street scene of Jews who are being rained upon by Celan's schwarze Flocken. This is the crucial point in the paratextual commentary of the score, linking Brahms directly with the rise of anti-Semitism and, ultimately, the Holocaust. Later in the score, on page 15, Brahms is shown on his death bed, and on page 18 there is a picture of his funeralimmediately opposite the blacked out image representing the eradication of the Jewish presence in Europe (figure 1). Cherney implies that while Brahms's death may exonerate him from direct responsibility for the Holocaust, the connections are nevertheless clear and direct.

As his work Brahms and the German Spirit demonstrates, Cherney's career as a scholar-composer arises naturally out of his Jewish heritage and his ongoing attempt to understand life's big questions. How could the tolerant and cosmopolitan atmosphere of the Weimar era disappear into the horrors of Nazi Germany and the Holocaust? What role did music and musicians play in this transformation? How can we come to terms with that terrible legacy? What role should composers play in society, and how can they make their creative work meaningful and relevant? Searching for answers to questions such as these has been a life's work for Cherney. These are questions that cannot be answered within any simple or single framework. In bringing both scholarly and creative perspectives to bear on such issues, Cherney continues to provide insight and inspiration, not just to musicologists or composers, but to all thinking human beings.

22 The source for this remark is the memoir of the composer Richard Heuberger, Erinnerungen an Brahms, quoted in Notley $(1993,111)$.

23 This statement, too, is taken from Heuberger's Erinnerungen an Brahms. Notley apologetically goes on to observe that even "many Liberal Jews in Vienna shared the composer's prejudice against the Galician Jews." 


\section{REFERENCES}

Attfield, Nicholas. 2017. Challenging the Modern: Conservative Revolution in German Music 1913-1933. Oxford: Oxford University Press, for the British Academy.

Beckwith, John. 1975. "Music Criticism." Globe and Mail, 7 October.

- - et al, comp. 1990. Alumni Directory, University of Toronto Faculty of Music, with a historical introduction by Ronald Chandler. Toronto: The Faculty.

Beckwith, John, and Brian Cherney, eds. 2011a. "A Self-Made Composer." In Beckwith and Cherney 2011b, 3-26.

- 2011b. Weinzweig: Essays on His Life and Music. Waterloo, ON: Wilfrid Laurier University Press.

Beller-McKenna, Daniel. 2004. Brahms and the German Spirit. Cambridge, MA: Harvard University Press.

Betts, Lorne. 1971. "Music: Winner a 'Piece of Nonsense." Spectator [Hamilton], 4 March.

Blessinger, Karl. 1944. Judentum und Musik, ein Beitrag zur Kultur- und Rassenpolitik. Berlin: B. Hahnefeld.

Cherney, Brian. 1973. "The Bekker-Pfitzner Controversy (1919-1920): Its Significance for German Music Criticism during the Weimar Republic (19191932)." PhD diss., University of Toronto.

—_.1974. "Conversation between Brian Cherney and John Rea." Array Newsletter 2, no. 1 (Fall): 9-19.

—.1975a. Harry Somers. Canadian Composers / Compositeurs Canadiens, no. 1. Toronto: University of Toronto Press.

_ _ 1975b. "Somers, Harry." Contemporary Canadian Composers, ed. Keith MacMillan and John Beckwith, 207-14. Toronto: Oxford University Press.

_. 1980. "Somers, Harry." New Grove Dictionary of Music and Musicians, ed. Stanley Sadie. London: MacMillan.

__ 1981. "Somers, Harry." Encyclopedia of Music in Canada, ed. Helmut Kallmann, Gilles Potvin, and Kenneth Winters, 881-3. Toronto: University of Toronto Press.

- 2009. Brahms and the German Spirit, for clarinet, cello and optional piano. Ms.

—. 2011. "The Activist." In Beckwith and Cherney 2011b, 47-73.

_. 2014. "Pierre Mercure: Aborder la modernité." In La Création musicale au Québec, ed. Jonathan Goldman, 15-38. Montreal: Les Presses de l'Université de Montréal.

—_ coord. 2018. "Celebrating Canada: Concert of Canadian Music." Concert program and program notes. https://www.mcgill.ca/music/channels/ event/celebrating-canada-concert-canadian-music-269483.

Cornfield, Eitan, and Hele Montagna. 2005. Canadian Composers Portraits: Brian Cherney. Centrediscs CMCCD 10405. Transcription by Mara Zibens, https://www.musiccentre.ca/sites/www.musiccentre.ca/files/resources/pdfmedia/cherney-portrait-en.pdf.

Desjardins, Jacques. 1999. "Brian Cherney et Bruce Mather: la clairvoyance du compositeur solitaire." Circuit: musiques contemporaines 10 (2): 17-28. 
Elliott, Robin. 1990. “The String Quartet in Canada.” PhD diss., University of Toronto.

Fay, Brendan. 2013. "The Promise of Tradition: Music, Modernity and Mass Society in Weimar Germany." PhD diss., Indiana University.

Felstiner, John, trans. and ed. 2001. Selected Poems and Prose of Paul Celan. New York: W.W. Norton.

Franklin, Peter. 1989. "Audiences, Critics and the Depurification of Music: Reflections on a 1920s Controversy." Journal of the Royal Musical Association 114 (1): 80-91.

Gillmor, Alan. 1977. Review of Contemporary Canadian Composers, edited by Keith MacMillan and John Beckwith, and Harry Somers by Brian Cherney. Contact: Today's Music 17 (Summer): 30.

Hailey, Christopher, comp. 1993. Register to the Paul Bekker Papers, MSS 50. Yale University Library / Irving S. Gilmore Music Library http://ead-pdfs. library.yale.edu/10638.pdf.

.1994. "The Paul Bekker Collection in the Yale University Music Library." Notes 51 (1): 13-21.

Helmer, Paul. 2009. Growing with Canada: The Émigré Tradition in Canadian Music. Montreal and Kingston: McGill-Queen's University Press.

Kater, Michael H. 2000. "Hans Pfitzner, Magister Teutonicus Miser." Composers of the Nazi Era: Eight Portraits, 144-82. New York: Oxford University Press.

Keillor, Elaine. 1994. John Weinzweig and His Music: The Radical Romantic of Canada. Composers of North America, no. 15. Metuchen, NJ: Scarecrow.

Kraglund, John. 1975. "A Theme Lost in Pedantry." Globe and Mail, 27 September.

MacMillan, Keith, and John Beckwith, eds. 1975. Contemporary Canadian Composers. Toronto: Oxford University Press.

Maskell, Chris. 2017. "Brian Cherney: Highlights in Canadian Music." Blog post. https://www.mcgill.ca/music/channels/news/brian-cherney-highlightscanadian-music-267041 (accessed 12 June 2018).

Nielsen, Nanette. 2018. Paul Bekker's Musical Ethics. London: Routledge.

Notley, Margaret. 1993. "Brahms as Liberal: Genre, Style, and Politics in Late Nineteenth-Century Vienna." 19th-Century Music 17 (2): 107-23.

Olnick, Harvey J. 1959. “Harry Somers." Canadian Music Journal 3 (4): 3-23.

Pace, Ian. 2018. "The Reconstruction of Post-War West German New Music During the Early Allied Occupation (1945-46), and its Roots in the Weimar Republic and Third Reich (1918-45)." PhD diss., Cardiff University.

Pittenger, Elise. 2010. "Visible Music: Instrumental Music Theatre. Shaping Sight and Sound in Instrumental Music." DMus diss., McGill University.

Roberge, Marc-André. 1994. "Focusing Attention: Special Issues in German-Language Music Periodicals of the First Half of the Twentieth Century." Royal Musical Association Research Chronicle 27:71-99.

Rockwell, John. 1972. "The Prussian Ministry of Culture and the Berlin State Opera, 1918-1931." PhD diss., University of California at Berkeley.

-2006. "Idealism and Innocence: The Failure of Opera Reform in the Late Weimar Republic." In Late Thoughts: Reflections on Artists and Composers 
at Work, ed. Karen Painter and Thomas Crow, 183-205. Los Angeles: Getty Research Institute.

Ross, Alex. 2007. "Death Fugue: Music in Hitler's Germany." In The Rest Is

Noise: Listening to the Twentieth Century, 333-70. New York: Picador / Farrar, Straus and Giroux.

Swafford, Jan. 1997. Johannes Brahms: A Biography. New York: Alfred A. Knopf. Taruskin, Richard. 1993. Mussorgsky: Eight Essays and an Epilogue. Princeton, NJ: Princeton University Press.

Weiner, Marc. 1993. Undertones of Insurrection: Music, Politics, and the Social Sphere in the Modern German Narrative. Lincoln: University of Nebraska Press.

Williamson, John. 1992. The Music of Hans Pfitzner. Oxford: Clarendon.

\begin{abstract}
While best known as a composer, Cherney has also been active in music scholarship. His doctoral thesis in musicology was on German music criticism during the Weimar era, but in his later career he has made important and timely interventions into Canadian music studies. Among his publications are articles on John Weinzweig and Pierre Mercure, as well as a monograph on Harry Somers, who is the subject of his ongoing research. His course on Canadian music at McGill University has introduced many students to the serious study and understanding of composed music in Canada. This article considers Cherney's music scholarship and speculates on how this work may have had an impact upon his creative activities as a composer.
\end{abstract}

\title{
RÉSUMÉ
}

Bien que connu surtout comme compositeur, Cherney a aussi été actif dans le milieu de l'érudition musicale. Sa thèse de doctorat en musicologie portait sur la critique musicale sous la République de Weimar; plus tard dans sa carrière, il a aussi fait des interventions importantes et opportunes dans le domaine des études musicales au Canada. Ses publications incluent des articles sur John Weinzweig et Pierre Mercure, ainsi qu'une monographie sur Harry Somers, qui fait l'objet de sa recherche en cours. Son cours sur la musique canadienne à l'Université McGill a initié de nombreux étudiants à l'étude sérieuse et la compréhension de la musique composée au Canada. Cet essai porte sur l'érudition musicale de Cherney et pose comme hypothèse que cette optique peut avoir influencée ses activités créatrices comme compositeur.

\section{BIOGRAPHY}

Robin Elliott was appointed to the Jean A. Chalmers Chair in Canadian Music in the Faculty of Music at the University of Toronto in 2002. The main focus of his scholarly work is composed Canadian music; he has produced a dozen books and editions of music (as author or editor), and 100 articles of varying length. He was the English editor of Intersections from 2014 to 2016. 